DOI: $10.20472 /$ TEC.2019.007.001

\author{
MOHAMAD ADNING \\ Brunel University of London , United Kingdom
}

DIANA SARI DJ

Quality Insurance of Education Institute, Lampung Province, Indonesia, Indonesia

KULSUM NUR HAYATI

Development Center for Radio Media Education and Culture, Yogyakarta, Indonesia, Indonesia

\title{
TEACHER PERCEPTION USING THE MOBILE PHONE IN THE TEACHER WORKING GROUP; AGE MATTERS
}

\begin{abstract}
:
This study examined senior teachers and junior teachers at primary school to show their mobile phone activity level among teacher working group in Lampung Province in 5 districts. The category of junior teachers are teachers whom are under 32 years (246 teachers) and senior teachers are categorised among teachers whom are over 50 years (304 teachers) and the total respondent is 550 teachers. There are two main elements of this research. Firstly, there is perception on the activity on junior teachers and senior teachers in primary school in teacher working group in Lampung Province. The research found that senior teachers are more active and care about being a part of teacher working group as compared to junior teachers, but both of them said that teacher working group helps them to improve their competencies. Secondly, there is a perception of the activity by junior teachers and senior teachers in the mobile phone group chat in the teacher working group. The result indicates that the junior teachers perceive themselves as experts $(63 \%$ of the respondents) in using mobile phone, higher than senior teachers (23\%). The result has also found that not all junior teachers were engaged in the group chat in teacher working group (72\%), and the same pattern was seen among senior teachers as only $75 \%$ of them were engaged in group chat. There is a different perception of activity between junior teachers and senior teacher in collaborative learning through the mobile phone in teacher working group based on t-test with an independent sample test. The data indicates ( 2 tailed) 0.011 compare to the table $<0.05$, which means there is a different perception of activity in collaborative learning using mobile phone between junior teachers and senior teachers in teacher working group.
\end{abstract}

\section{Keywords:}

Teacher working group, mobile phone, teacher

JEL Classification: 120, 121, 129 


\section{Introduction}

Indonesia has received an exponential increase of teacher over the last decade. The current number of teachers at Indonesia has reached to 3,337,914 teachers (PDSPK Kemendikbud, 2018) and this calls for equipping the teachers with academic qualifications, competencies, professional certificates, healthy body and spirit, and the ability to embody the national education achievement (Indonesia, 2005). To achieve this vision, the government of Indonesia has realised the role of professional teachers in ensuring quality education. As stated by Rasyid (2015), professional teachers are vital to quality education because the process of learning process is the core of education and learning is essentially depending on the quality of professional teachers. Rasyid (2015) added that discourse can improve competencies and this makes professional teacher as one of the priorities in the education system.

Teacher working group (KKG) has been recognised as one of the strategies that teachers can use to improve their level of competencies. KKG is a social community that has been approved by the government of Indonesia and it aims to improve the competencies and skill of professional teachers. Resmini (2010) recognised the importance of teacher working group as it is an integral part of the education counselling system where teachers can receive proper aids in improving their quality and enhancing their skills as a professional teacher. Specifically in LPMP Lampung Province (2017, 2018), KKG has been recommended to improve the qualification and skill of teacher due to Lampung Province was placed at low scores in teacher competencies at the national rate (LPMP Lampung, 2018). As professional teacher is one of the important factors in education, empowering teacher working group is vital as it can be used as the platform for teachers to improve their skill, knowledge and competencies and eventually, strive to be a professional teacher.

The increasing number of mobile phone users has made the mobile phone to become a part of human's daily life. In Indonesia, $50.08 \%$ people have mobile phone or tablet (Assoscation, 2017; O'Bannon and Thomas, 2014) and mobile phones are used in numerous activities, including teaching, learning, work and leisure (Kukulsk et al , 2009). In fact, there are studies that illuminated the connection between mobile phones application in schools and success in attaining critical skills for future employment (Clarke and Svanaes, 2015; O'Bannon and Thomas, 2014). In retrospect, past studies have highlighted that using mobile phones in collaborative learning is not only beneficial for students, but also teachers. Specifically, recent evidence has shown that teachers will be more likely to learn with peers who share similar characteristics such as age, subject and location and will unlikely to cross the border of age and status (J. Park et al., 2010; Y. Park, 2011; Ryu and Parsons, 2012).

Aubusson et al (2009) described that the research on the mobile learning in education has focused primarily on student learning, and on the ways that teachers can support 
this learning. As a result, there is currently insufficient research on how the teachers themselves might learn with these new technologies, or with other digital technologies (Aubusson et al, 2009). At best knowledge, no previous study has been conducted to investigate on how collaborative learning via mobile phone can affect teachers' competencies and how status, age and location can influence the use of mobile phones to improve the competencies.

Therefore, this study calls to find out the perception of teachers in collaborative learning activity among teacher working group through the use of mobile phone. For this reason, the perception of senior teachers and junior teachers at primary school was examined to show the level of activity of community work among teachers in Lampung Province in 5 districts through the use of mobile phone.

\section{Literature review}

\section{II.1. Teacher working group}

Several countries have recognised teacher working group as a professional learning community. In Indonesia, teacher community work is under regulation 070/ C/ Kep/ 1/93 that was outlined on $7^{\text {th }}$ April 1993 (Al Rasyid, 2015). By having the regulation, the teacher working group is revitalised as guidelines and standards were outlined to guide the group. For example, the Guideline for Teacher Working Group, Operational Standard Teacher Working Group and Procedure Operational Standard Develop Curriculum on Teacher Working Group (Depdiknas, 2008; Kemdiknas, 2010). Al Rasyid (2015) stated that through teacher working group, teachers are receiving the necessary aid to conduct their responsibilities in the teaching profession as teacher working group focuses in talking and discussing subject material as well as developing the media material.

In essence, the Government of Indonesia hopes that teacher working group will enhance teachers' competencies (Resmini, 2010) and the government has set several aims to be achieved through the establishment of teacher working group. The primary objective is to provide more understanding and knowledge in numerous fields, especially to master the substance of material subject, creating good lesson plan, developing learning material, learning strategy and learning methods, maximising the equipment and facility that they have and utilising learning resources and giving feedback to members of a group (Depdiknas, 2008). There is a national project namely Program Peningkatan Kompetensi Pembelajaran Berbasis Zonasi (PKP) (initial in English; Zoning based Learning Competency Improvement Program) and this program is a part of the strategy to accelerate the development in the education field, quality and system through teacher working group (Lisdiana at al., 2018). Recently, the Government of Indonesia has started to give incentive to teacher working group to encourage the utilisation of teacher working group as the primary factor in improving teachers' competencies and to become professional teacher. 
Teacher working group provides programs to support and it is the platform to refer on any matters regarding teachers' competencies and professional teacher. There are several ways to create programs or event in teacher working group, and the first step is to analyse the teachers' need and how to prioritise teacher working group on calendar years (Kemdiknas, 2010). It can be started either from the general program, core program or supporting program. Kemdiknas (2010) said that teacher working group should be conducted at least once a month, and teacher working group should have a leader that is elected based on the vote from the members. Moreover, the operational or budgeting of teacher community works should come from the annual members of the teacher, operational school where the teacher teaches (BOS), funding from the government or local government and it also can come from school communities (Kemdiknas, 2010). In turn for the funding, the government expects teachers to be active in any event, or workshop created by teacher community work. However, the reality on the field is not answering to the expectation of the government.

\section{II.2. Mobile Phone}

Mobile phone is one of the tools that is used for mobile learning. Park (2011) stated that mobile learning can come from numerous sources, be it cell phone, smartphone, palmtops, tablet PCs, laptops or personal media. Other experts defined mobile learning as a process of learning that is mediated by handheld devices such as smartphones, the tablet computer, and game consoles (llic, 2013; Kearney et al, 2015; Naismith et al, 2004). The features in the mobile phone have become the common tools in teaching, learning, work and leisure (Kukulsk et al., 2009). As a result, mobile phone is not only used for business affairs, but it has transcended into the education field as well and educators have taken the advantages to use mobile phones to enhance and transform their teaching practice.

Aubusson et al. (2009) described that mobile phone has become ideally suited to teachers as it provides a process of learning for professionals that is different from their common working and learning context. Being a teacher requires he or she to constantly move in their job, and mobile phone has become necessary for teachers to interact with people that are both beyond and within one's own school. In addition, mobile phones provide access to expertise that is situated outside of their range through the use of online learning environment, and it also helps to build personal and professional support networks (Aubusson et al., 2009). In essence, mobile phone will be help teacher to learn more knowledge, or getting sufficient information connected to their competencies.

Ilic (2013) suggested three main elements in the framework of the mobile phone, namely personalisation, authenticity and collaboration. The first elements of personalisation can help the learner to personally dictate his or her own pace and time of learning. Any activities of delivering content, texting, and feedback response, including the time spent 
on learning material and decision are on the hands of the learner. llic (2013) separated between personalisation in the mobile phone with personalised by e-learning especially on recognising the context and history of each learner and the delivery of learning that is dictated by the learner at any time and place.

The next element is authenticity. Ilic (2013) believed that authentic learning provides real-world relevance where it can be defined in terms of a) tasks, b) roles, and c) context. The situation on the mobile phone should reflect real problems from the real world, and it can be perceived on the practices that were carried out and the value of these practices. It was suggested that mobile phones should create learning activities that are relevant and interesting and based on problem-based lessons or projects. The last element is collaboration. Learners need to have the platform to communicate and to discuss. Currently, mobile phones have successfully created numerous tools to open the ways for learning collaboration through recording, organising and reflecting on learning. In addition, llic (2013) described that mobile learning enable learners to learn regardless of distance through mobile data collection and sharing, support transmission and delivery of rich multimedia content, and links can be made to both inside and outside the school.

\section{Research and Design Methodology}

This research is a quantitative research. In literature, numerous definitions of quantitative research have been made. Bacon- Shone (2015) said that quantitative research is a process to collect the data using the structural instruments such as questioner, survey or polling where the result of the analysis is based on the sample which is the representative from population. They believed that quantitative research prioritised objective data in assessing a social phenomenon (Bacon-Shone, 2015). The method for this research is questionnaire and the questionnaires were distributed online among teachers in Lampung province. Mardalis (2008) said that questionnaire is one of the techniques of collecting data using a form filled with a number of questions and respondents are required to answer the questions through writing and information for the research is gathered through the answer. There are several benefits of using a questionnaire in quantitative research. One of them is it can spread a big number of respondents with relatively short time, and the objectivity of respondent is guaranteed to be free from outside influences on researcher.

The questionnaires were created for primary school teacher in Lampung Province and the questions were aimed to obtain information on key themes included:1) demographic information, 2) collaboration activity in teacher working group, 3) mobile phone. The questionnaire used the mixed format design and the questions are formatted in a series of statements about collaborative activities in teacher community work and mobile phone applications with a rating scale (Never (1) rarely (2) sometimes (3), active (4), very active (5)). The questionnaire was also rated in the forms of ticking the boxes (e.g. 
yes or no), multiple choice questions (e.g. age group) and open-ended questions. The questionnaires were distributed in February 2019 and took 2 weeks to be completed. As the Province of Lampung has 13 districts and 2 cities, this study has limited the scope of the study to one third of the population of Lampung. Specifically, 3 districts (Lampung Tengah, Tulang Bawang, Tulang Bawang Barat) and 2 cities (Metro and Bandar Lampung) were chosen as respondents and the study has managed to gather responses from 550 teachers.

\section{Result and discussion}

This study makes the effort to inquire several issues from both sides of teachers, the junior teacher and the senior teacher. These issues are the two main elements of this research. Firstly, this study seeks to analyse the perception of activities among on Primary schools' junior teachers and senior teachers in teacher working group in Lampung Province. Secondly, this study also seeks to analyse the perception of the activities of junior teachers and senior teachers in mobile phone group chat in the teacher working group.

The study begins by analyzing the perception of activities junior teachers and senior teachers in primary school in teacher working group in Lampung province. Based on the data, the result has found that almost $98 \%$ or 298 senior teachers are a part of the teacher working group compared to junior teachers are 199 teachers (81\%) (Figure 1).

Figure 1: Percentage of teachers who join the teacher community work

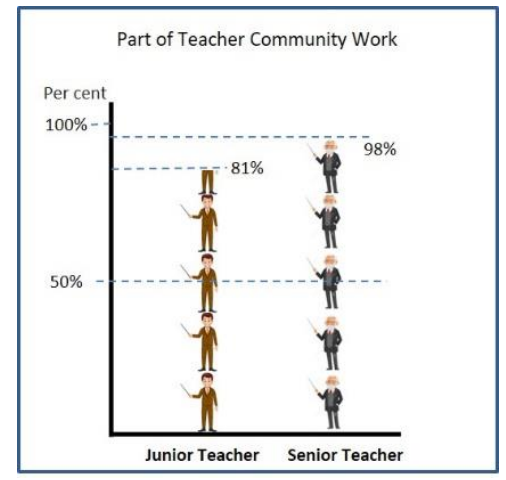

Further analysis of the data showed that both junior teachers and senior teachers have benefited from teacher working group as the group has been instrumental in improving the competencies of the teachers. The most help that they have received from teacher working group are issues in pedagogies and professional competencies. However, both group did voice out their requests on other skills that they need help from the teacher working group, namely improving their computer or information and communication 
technology skills, teaching methodology, lesson plans and students' assessment. In terms of active participation, the data showed that not all members are active, but about two third (69\%) of junior teachers were considered as active and senior teachers was also found to be on par with the junior teachers $(65 \%$ of senior teachers are active on learning group created by teacher working group, and $23 \%$ senior teacher said sometimes they joined the learning group). In general, the result found that senior teachers were more active in teacher community as compared to junior teacher.

Secondly, the research analysed the level of the contribution in group chat through the use of mobile phones among teacher working group. The result found that almost $100 \%$ junior teachers have smart phone with internet data, but $91 \%$ senior teachers have smart phone. The result indicates the junior teachers have considered themselves to be expert (63\% of the respondents) in using mobile phone, as compared to their counterpart, senior teachers. In fact, only $23 \%$ of senior teachers considered themselves as expert. Moreover, the study has found that over the half of junior teachers $(69 \%)$ have received information and knowledge by mobile phone, contrast to senior teacher of only $44 \%$.

The result has also found that not all junior teachers were engaged in the group chat in teacher working group $(72 \%)$, and the same pattern was seen among senior teachers as only $75 \%$ of them were engaged in group chat. Moreover, senior teachers were slightly more active (59\%) compare to junior teachers (57\%) in group chat. This shows that mobile phones are becoming the common medium for individual to conduct their activity. This is similar to the statement made by Kukulsk et al (2009) that believed mobile phone has become more common to be used in teaching, learning, work and leisure. Additional questions were asked to probe into the activity in the group chat. It was found that junior teachers were more active $(52 \%)$ to share information about teacher competencies rather than the senior teachers (34\%) in teacher working group. To sum up, the result indicates that junior teachers are perceptively more capable of using the mobile phones than the senior teachers. The study deemed that the junior teachers are the experts of using mobile phone and they are more keen to discuss with colleagues in the teacher working group about teaching knowledge. However, in general discussion in group chat senior teacher slightly more active compared to junior teachers

Furthermore, the research moved to employ $t$ test with independent sample test between junior teacher and senior teacher (table 1 and 2).

Table 1: Group Statistics

\begin{tabular}{|l|l|r|r|r|r|}
\hline & Age & \multicolumn{1}{|c|}{ N } & \multicolumn{1}{c|}{ Mean } & Std. Deviation & Std. Error Mean \\
\hline \multirow{2}{*}{ Collaboration mobile } & $<32$ year & 246 & 3.2886 & .81943 & .05224 \\
\cline { 2 - 6 } & $>50$ year & 304 & 3.4474 & .64781 & .03715 \\
\hline
\end{tabular}


Based on the table above, it shows that junior teachers (under 32 years old) has mean scores of 3.2886 whereas senior teacher (over 50 years old) has the mean scores of 3.4474. Meanwhile, the value point shows that the average number of activity collaboration through mobile phone on group senior teachers is 3.2886 and the average value point for group junior teachers is 3.4474 . This shows that the collaborative activity via mobile phone in teacher working group was higher among senior teachers than junior teachers

To test the difference, the Independent-sample $\mathrm{T}$ Test was conducted using SPSS version 23 for Windows, and the result is shown in table 2.

Table 2: Independent Samples Test

\begin{tabular}{|c|c|c|c|c|c|c|c|c|c|c|}
\hline & \multicolumn{2}{|c|}{$\begin{array}{l}\text { Levene's } \\
\text { Test for } \\
\text { Equality of } \\
\text { Variances }\end{array}$} & \multicolumn{7}{|c|}{ t-test for Equality of Means } \\
\hline & & \multirow[b]{2}{*}{$\mathrm{F}$} & \multirow[b]{2}{*}{ Sig } & \multirow[b]{2}{*}{$\mathrm{t}$} & \multirow[b]{2}{*}{$\mathrm{df}$} & \multirow[b]{2}{*}{$\begin{array}{l}\text { Sig. (2- } \\
\text { tailed) }\end{array}$} & \multirow{2}{*}{$\begin{array}{c}\text { Mean } \\
\text { Differen } \\
\text { ce } \\
\end{array}$} & \multirow{2}{*}{$\begin{array}{c}\text { Std. } \\
\text { Error } \\
\text { Differen } \\
\text { ce } \\
\end{array}$} & \multicolumn{2}{|c|}{$\begin{array}{c}95 \% \\
\text { Confidence } \\
\text { Interval of the } \\
\text { Difference } \\
\end{array}$} \\
\hline & & & & & & & & & Lower & $\begin{array}{c}\text { Uppe } \\
\mathrm{r} \\
\end{array}$ \\
\hline $\begin{array}{l}\text { Collaborati } \\
\text { on mobile }\end{array}$ & $\begin{array}{l}\text { Equal } \\
\text { variances } \\
\text { assumed } \\
\text { Equal } \\
\text { variances not } \\
\text { assumed }\end{array}$ & $\begin{array}{r}16.54 \\
8\end{array}$ & $\begin{array}{r}.00 \\
0\end{array}$ & $\begin{array}{r}2.537 \\
- \\
2.476\end{array}$ & $\begin{array}{r}548 \\
\\
460.2 \\
89\end{array}$ & 011 & $\begin{array}{r}-.15875 \\
-.15875\end{array}$ & .06256 & - & $\begin{array}{r}- \\
.0358 \\
5 \\
- \\
.0327 \\
7\end{array}$ \\
\hline
\end{tabular}

Based on the table, it shows that there is a different perception of activity between junior teachers and senior teacher in collaborative learning through the mobile phone in teacher working group. The data indicates that the score for the 2 tailed test is 0.011 and comparing to the table $<0.05$, it shows that there is a different perception of collaborative learning activity via the use of mobile phone between junior teachers and senior teachers in teacher working group.

\section{Conclusion}

In general, the teachers on Lampung Province can be considered as active in teacher working group and additionally, they are also active in using their mobile phones to find information and knowledge that they need to improve their competencies. Even though not all members of teachers working group are a part of the mobile phone group chat, 
but in general senior teachers are more active in teacher community compared to the junior teacher. Generally, most primary school teacher in Lampung province use their mobile phone to conduct their activity. However, senior teachers were found to have the lower capability to utilise their mobile phones, as compared young teacher. The differences of skills of mobile phone use presents the opportunity for the Lampung province to encourage more activities to empower the teachers to utilise the mobile phone in their learning process to become professional teachers.

In response to this study, a call for future study to examine the integration of technology among teachers in teacher working group. Future studies should look into what platform in the mobile phones are used to stimulate mobile learning to help teacher to increase their competencies. As this study does not in depth on the information, skill and knowledge that were distributed via mobile phone in teacher working group, future studies that study in-depth regarding what are disseminated and what are expected in teacher working group should be conducted. The data from the suggested future studies can help to find more concrete data on the use of mobile phone to train the teachers to increase their competencies to become professional teachers.

\section{References}

Al Rasyid, H. (2015). Fungsi Kelompok Kerja Guru Bagi Pengembangan Keprofesionalan Guru Sekolah Dasar. Prodi PGSD Universitas Trunojoyo, 24 nomor 2(12), 143-150. Retrieved from http://download.portalgaruda.org/article.php?article=461652\&val=5095\&title=FUNGSI

KELOMPOK KERJA GURU (KKG) BAGI PENGEMBANGAN KEPROFESIONALAN GURU SEKOLAH DASAR

Assoscation, I. I. service provider. (2017). Penetrasi \& Perilaku Pengguna Internet Indonesia (Vol. 2018). Retrieved from file://acfs4/Ig18/lg18mas/Downloads/0ZQN3KJD69alp5PGhfOB7cxmivTSXd.pdf

Aubusson, P., Schuck, S., \& Burden, K. (2009). Mobile learning for teacher professional learning: benefits, obstacles and issues. Alt-J, 17(3), 233-247. https://doi.org/10.1080/09687760903247641

Bacon-Shone, J. (2015). Introduction to Quantitative Research Methods pres. In Loughborough Univeristy. https://doi.org/10.13140/2.1.4466.3040

Clarke, B., \& Svanaes, S. (2015). Updated Review of the Global Use of Mobile Technology. Techknowledge, (December), 1-21.

Depdiknas, D. profesi pendidikan. (2008). Standar pengembangan Kelompok Kerja Guru (KKG) dan Musyarah Guru Mata Pelajaran (MGMP).

llic, P. (2013). The Impact of Mobile Phones on Collaborative Learning Activities Submitted. Retrieved 
from https://ethos.bl.uk/SingleOrder.do?orderNumber=THESIS01834663

Indonesia, R. Undang-Undang Republik Indonesia Nomor 14 Tahun 2005 Tentang Guru dan Dosen. , Pemerintah Indonesia § (2005).

Kearney, M., Burden, K., \& Rai, T. (2015). Investigating teachers' adoption of signature mobile $\begin{array}{lllll}\text { pedagogies. Computers } \quad \text { and } & \text { Education, }\end{array}$ https://doi.org/10.1016/j.compedu.2014.08.009

Kemdiknas, D. P. M. P. dan T. K. (2010). Prosedur Operasional Standar Penyelenggaraan KKG Dan MGMP.

Kukulsk, A., John, A.-H., Tit, P., Kukulska-Hulme, A., \& Pettit, J. (2009). Practitioners as Innovators: Emergent Practice in Personal Mobile Teaching, Learning, Work, and Leisure. Retrieved from http://oro.open.ac.uk/15502/1/07_Mohamed_Ally_book_2009-Article7.pdf

Lisdiana, Ana, Handyani, Diny, Ariyana, Y. (2018). Pedoman program peningkatan kompetensi pembelajaran berbasis zonasi.

Mardalis. (2008). Metode penelitian suatu pendekatan proposal. Jakarta: Bumi Aksara.

Naismith, L., Lonsdale, P., Vavoula, G., \& Sharples, M. (2004). Literature Review in Mobile Technologies and Learning Literature Review in Mobile Technologies and Learning. Futurelab Series, Report 11, (May 2014), 48. Retrieved from http://www.nfer.ac.uk/publications/FUTL15/FUTL15_home.cfm

O'Bannon, B. W., \& Thomas, K. (2014). Teacher perceptions of using mobile phones in the classroom: Age matters! Computers and Education, 74, 15-25. https://doi.org/10.1016/j.compedu.2014.01.006

Park, J., Parsons, D., \& Ryu, H. (2010). To flow and not to freeze: Applying flow experience to mobile learning. IEEE Transactions on Learning Technologies, 3(1), 56-67. https://doi.org/10.1109/TLT.2010.1

Park, Y. (2011). A Pedagogical Framework for Mobile Learning: Categorizing Educational Applications of Mobile Technologies into Four Types. International Review of Research in Open and Distance Learning, 12.2, 78-102. https://doi.org/10.3394/0380-1330(2006)32

PDSPK Kemendikbud, I. (2018). Rangkuman Statistik Persekolahan. Retrieved from http://publikasi.data.kemdikbud.go.id/uploadDir/isi_2B40A310-F17C-4315-AF341FBA51252C56_.pdf

Provinsi Lampung, L. (2017). Peta dan Analisis Mutu Pendidikan Provinsi Lampung. Lampung.

Provinsi Lampung, L. (2018). Peta dan Analisis Mutu Pendidikan Provinsi Lampung. Lampung. 
Resmini, W. (2010). PEMBINAAN KEMAMPUAN PROFESIONAL GURU MELALUI KELOMPOK KERJA GURU ( KKG ). GaneÇ Swara, 4(1), 59-62.

Ryu, H., \& Parsons, D. (2012). Risky business or sharing the load? - Social flow in collaborative mobile $\begin{array}{llll}\text { learning. Computers } \quad \text { and } & \text { 587-72), }\end{array}$ https://doi.org/10.1016/j.compedu.2011.09.019 